\title{
Socioeconomic Status and its Impact on Language and Content Attainment in CLIL Contexts
}

\author{
Diego J. RAscón MoReno \\ University of Jaén \\ Carmen M. Bretones Callejas \\ University of Almería
}

Received: 24 May 2017 / Accepted: 2 October 2017

ISSN: $1697-7467$

\begin{abstract}
This article deals with a crucial variable in CLIL settings: socioeconomic status, which was measured via parents' educational level (high, medium or low). It sheds light on the FL, L1 and subject content attainment of 129 bilingual learners in Primary Education and Compulsory Secondary Education schools in eastern Andalusia (more specifically, in the provinces of Granada and Almería). It provides a detailed comparison of these outcomes with those also obtained from 219 students in traditional EFL streams. Six state and two charter schools participated. Differences in the motivation, verbal intelligence and extramural exposure of these students are also examined, together with their evolution from Primary to Compulsory Secondary Education. All the variables considered are subjected to discriminant analyses in order to determine which of them explains the greatest variance in language attainment and content achievement results.
\end{abstract}

Keywords: CLIL, socioeconomic status, FL, L1, subject content

El nivel socioeconómico y su impacto en el aprendizaje de lengua y contenido en contextos AICLE

RESUMEN: Este artículo se centra en una variable crucial en los entornos AICLE: el nivel socioeconómico, que se ha medido mediante el nivel educativo de los padres y las madres (alto, medio o bajo). Aporta luz sobre el aprendizaje de LE, L1 y contenido curricular de 129 estudiantes bilingües de centros de Educación Primaria y Educación Secundaria Obligatoria en el este de Andalucía (más concretamente, en la provincias de Granada and Almería). Asimismo, proporciona una comparación detallada de estos resultados con los también obtenidos por 219 estudiantes de grupos no bilingües. En la investigación han participado seis colegios públicos y dos concertados. También se analizan las diferencias en función de la motivación, inteligencia verbal y exposición extramural de los estudiantes, así como su evolución desde Primaria hasta Educación Secundaria Obligatoria. Todas las variables consideradas se someten a análisis discriminantes con el fin de determinar cuál de ellas explica la mayor parte de la varianza en los resultados de desarrollo lingüístico y aprendizaje de contenido.

Palabras clave: AICLE, nivel socioeconómico, LE, L1, contenido curricular 


\section{INTRODUCTION}

Perhaps the strongest criticism against CLIL since the term emerged in the 1990s (Pérez Cañado, 2012: 315) has been its purported lack of egalitarianism. This has been primarily embodied by Bruton (2011a, 2011b, 2013) and Paran (2013), although they have not been the only authors who have sounded a note of caution in this respect. Despite the fact that students and their parents can freely choose whether to study in a group following this innovative methodology or in a traditional foreign language (FL) class, it has been claimed that this selection is done -to a greater extent- on the basis of the socioeconomic status (SES) of the family (and the learner's motivation, intelligence and linguistic proficiency, to a lesser extent).

On the one hand, the possibility in itself of choosing between bilingual and monolingual strands has been considered as favoring egalitarianism, not hindering it, by Pérez Cañado (2016: 9) and Lorenzo, Moore and Casal (2011: 453). For the former, at least in Andalusia, we cannot talk of "imposed streaming" (Bruton, 2013: 593 used the term "disguised streaming") and the latter justify it following the interpretation of "free choice" as "equality" by Andalusian policy-making.

On the other hand, it is not far-fetched to connect social class and parental choice as Bruton does (2011a), especially after witnessing a mini-conference in which most CLIL teachers who attended linked the participation in bilingual programmes to children of higher socioeconomic status. Moreover, he refers to a study (Alonso, Grisaleña \& Campo, 2008) in which $65 \%$ of the CLIL pupils' parents had completed university education.

In any case, it is clear that the doubts about CLIL being egalitarian can be shot down in the contexts where it is no longer possible to choose traditional foreign language learning. As Pérez Cañado (2016: 9) wonders, "what greater equality of opportunity can there be than making CLIL programme-wide in compulsory public education stages?". This is the situation now in Andalusian public schools that have been offering CLIL programmes for five or more years. Consequently, positive scenarios (for CLIL supporters) will result, such as the city of Granada, where -from the 2015-2016 academic year onwards- no CLIL public school has monolingual groups for Primary Education (see Pérez Cañado, 2016). The goal of this Spanish autonomous community's education administration is that all CLIL schools be fully bilingual by 2020 .

However, it is convenient to contribute to the debate of whether CLIL succeeds because it is elitist and of whether its effects are ascribable to self-selection through solid empirical research, and this is precisely what this study seeks to do. It focuses on the southern Spanish provinces of Granada and Almería. A total of 348 students from eight educational institutions offering Primary or/and Secondary Education participated.

After referring to investigations that have already addressed the topic of SES in CLIL, the design of the investigation is described. There is an emphasis on the ways in which it has overcome the lacunae detected in prior research and that have been voiced by Bruton (2011a, 2011b), Paran (2013) and Pérez Cañado (2012, 2016). Then, the article shows the results obtained by CLIL and non-CLIL groups in Primary and Compulsory Secondary Education (CSE), not only in the acquisition of the English language (FL), but also in Spanish language (L1) and subject content (Natural Science), examined according to the variable of SES. It also considers students' motivation, verbal intelligence and extramural exposure, 
filtered through SES, and includes discriminant analyses to determine which variables best explain the differences ascertained. Finally, the chief conclusions and pedagogical implications that can be derived from this study are mentioned.

\section{Prior Research}

Of the various kinds of attainment under study here, investigations have mainly been focused on the effects of CLIL on the L2/FL. The consequences of dual-focused education on the students' L1 and content subject competence have not been addressed as much (Pérez Cañado, 2012: 331; Paran, 2013: 331; Alejo \& Piquer-Píriz, 2016; Fernández-Sanjurjo, Fernández-Costales \& Arias Blanco, 2017: 2).

There has also been consensus in the last few years that the future research agenda on CLIL should remedy the flaws of previous studies. Most importantly, the focus should be on introducing a series of variables (Pérez Cañado, 2012, 2016). Among them, there is a dire need for controlling socioeconomic status because it is one of the factors to which the success of CLIL has been ascribed by some authors, arguing that even the self-selection to participate in the programme is quite likely conditioned by the social class of the children's parents (Bruton, 2011a, 2011b, 2013).

Two prior investigations that have measured the variable of SES must be highlighted. Both of them focused on the content subject of Natural Science at Primary Education level. The first piece of research is that of Anghel, Cabrales and Carro (2016). Their sample comprised sixth-grade students in the Spanish region of Madrid who had finished their first compulsory schooling stage in the 2009-2010 and 2010-2011 academic years. They belonged to the first and second groups of schools which became bilingual in 2004-2005 and 2005-2006.

In order to determine the results of the bilingual programme, the authors used the standardized exam that has been administered to sixth graders in Madrid from the start of the initiative (2004-2005). These anonymously chosen students had to complete a questionnaire including a series of socioeconomic background items, and researchers benefited from this information to factor in the variable. Results indicate that parental educational level affects the cohorts' knowledge of Natural Science. Students with parents that had only finished lower-secondary education performed more poorly in the exam than those with parents with university, higher secondary or vocational training.

Even more recently, Fernández-Sanjurjo, Fernández-Costales and Arias Blanco (2017) have undertaken the other methodologically sound CLIL study controlling the socioeconomic variable. They carried it out in Asturias, a monolingual autonomous community in North Spain. The sample was composed of 709 students, pertaining to traditional and dual-focused education at similar percentages $(50.4 \%$ vs. $49.6 \%)$. The number of participants was a representative enough sample of the region.

Children belonged to schools either in urban or semi-urban areas. Rural ones were discarded for the understandable reasons the authors give (accounting for less than $20 \%$ of the student population and the majority of them being Grouped Rural Schools, which have some characteristics that exclude them from the study). The sample of 18 institutions was balanced concerning their location in all urban and semi-urban areas, and their social and economic context. Pupils in the CLIL streams had participated in the programme since they entered Primary Education, and the schools had six years of experience in offering this methodology. 
SES was measured through a survey and the investigators created a test to determine the level of science content. They were properly validated, both by a group of experts and by means of a pilot study. The survey followed the design of similar instruments used in international evaluations. It enquired into three dimensions, and included questions connected with "students' material and economic well-being, the type of cultural activities they are involved in, and the presence of cultural elements in the family environment (e.g. number of books at home)". Furthermore, the reliability of the Science test was estimated by Cronbach Alpha (0.790) (cf. Fernández-Sanjurjo, Fernández-Costales \& Arias Blanco, 2017: 5).

The results of this bi-variate study show that students performed differently according to status. Pupils coming from less privileged backgrounds did worse in the Natural Science test than those belonging to medium or high SES, who achieved similar scores. Differences between them are statistically significant. Other interesting findings are that students in CLIL and non-CLIL institutions were equally distributed in high, medium and low backgrounds, and that the latter produced a greater standard deviation. This study affirms that a connection can be established between poor performance on content and monolingual- and bilingual-stream students of low SES. The authors add that a need for further research exists. It is here where this article takes the baton.

\section{The STUdY}

This research is a quantitative analysis that studies the effects of socioeconomic status (SES) on non-CLIL and CLIL Primary and Secondary Education in two provinces of Andalusia, namely Granada and Almería. This research is framed within a broader research project (cf. Acknowledgements), which is a large-scale evaluation of CLIL programmes in three monolingual communities with the least tradition in bilingual education, i.e., Andalusia, Extremadura, and the Canary Islands.

The study not only measures SES, but also English language competence (grammar, vocabulary and the four communicative skills), Spanish language competence, content knowledge of Natural Science and some moderating variables such as verbal intelligence, motivation and extramural exposure.

Parents' educational level was taken as a proxy to measure the socioeconomic variable, and it was divided in the following categories according to the highest education level completed: low, medium or high.

\subsection{Research questions}

RQ1: What are the effects of SES on the FL of bilingual groups in Primary Education and CSE compared to those of the monolingual groups?

RQ2: What are the effects of SES on the L1 and content attainment of bilingual groups in Primary Education and CSE compared to those of the monolingual groups?

RQ3: What is the relationship between SES and the CLIL/non-CLIL subjects' verbal intelligence, motivation and extramural exposure from Primary Education to CSE?

RQ4: Which of the variables considered, if any, explain(s) the competence differential in FL, L1 and subject matter learning at the end of the two compulsory education stages? 


\subsection{Sample}

This study analyses a sample of 348 students in six state and two charter schools in the Spanish autonomous community of Andalusia, more concretely in its eastern provinces of Granada and Almería. 106 of the pupils (aged 11-12) were finishing sixth grade of Primary Education, whereas the rest, 242 (aged 15-16), were on the verge of completing fourth year of CSE. The majority of the cohort $(68.7 \%)$ was at state institutions where CLIL and nonCLIL streams coexisted, and the remaining $(31.7 \%)$ was enrolled in charter schools with only traditional EFL groups. There is almost a perfect balance in terms of setting, since 171 and 177 learners studied in rural and urban areas, respectively. The percentages as far as gender is concerned are very similar, but not identical, with a slight predominance of girls over boys $(55.5 \%$ vs. $45.5 \%)$.

Regarding the variable around which this article revolves, socioeconomic status, it must be remarked that the educational level of the children's parents was taken as a proxy for it. Using the information in this respect provided by students about their parents, we could classify the cohort into: low (their parents had no studies or just the compulsory ones), medium (their parents had finished Secondary Education/Vocational Training), or high SES (their parents had a university degree). When their parents did not have the same level of studies, learners were classified in one category or another according to the highest educational attainment of the couple. The data gathered shows similarity between mothers and fathers, but it confirms the popular belief that slightly more women than men reach higher education at the present time, at least in Spain, as can be seen below:

- Highest education level of the mother: low (38.9\%), medium $(25.4 \%)$ or high (35.7\%).

- Highest education level of the father: low (41.9\%), medium (26\%) or high (32.1\%).

On the other hand, at the start of the research we wanted to ensure that we were going to work with a homogenous sample in terms of verbal intelligence and motivation, since it has been often claimed (Bruton, 2011a, 2011b, 2013) that CLIL classes quite probably comprise the best students. Tests measuring both were administered to the first sample of schools, and the bilingual and monolingual groups' results were compared. Those institutions with the most homogenous experimental and control classes made up the final sample and participated in the next phase (the comparison of their FL, L1 and content attainment). In the rare cases when there were significant statistical differences on any of the two aspects, the "outliers" (participants obtaining very high or poor scores) were eliminated until there were no differences between the groups.

\subsection{Variables}

The variables of this study are of three types: dependent, independent, and moderating ones.

- The dependent variables are:

- The students' English language (FL) competence, namely grammar, vocabulary, listening, reading and speaking. 
- The students' Spanish language (L1) competence.

- The students' level of content attainment through CLIL, specifically of Natural Science subjects.

- The independent variable is:

- The CLIL programmes implemented in the different types of schools.

- The moderating variables are:

- Socioeconomic status (SES).

- Verbal intelligence.

- Motivation (including: desire to work, anxiety, lack of interest and self-demand).

- Extramural exposure.

\subsection{Instruments}

The main variable under investigation here, SES, has been measured by means of an initial questionnaire administered to students that comprised personal data about their parents' educational level. The other intervening variables of this study, verbal intelligence, motivation and extramural exposure, were controlled through a series of tests administered at the same time as the afore-mentioned survey.

The first two are previously validated and tried-and-tested instruments in the field of language teaching research or psychology. The former was part of Santamaría et al.'s battery of tests (2016), which intend to carry out a factorial evaluation of intellectual aptitudes. It was adapted to sixth grade of Primary Education and fourth grade of CSE students, who -in five minutes- had to try to complete 26 and 23 multiple-choice items, respectively, involving analogies, antonyms and odd-one-out exercises. The latter instrument was Pelechano's (1994) MA test, aimed at analyzing: (i) vain desire to work and self-esteem, (ii) anxiety in the face of exams, (iii) lack of interest in studying, and (iv) realistic personal self-demand. As for exposure to English outside the classroom, a tool based on Sundqvist \& Sylvén's (2014) questionnaire was designed.

In order to measure the dependent variables, we needed the students' final marks in L1 and Science, which were provided by each school out of a total score of 10. For FL competence we employed a battery of use of English, vocabulary and communicative skills exams created as part of the broader project to which this study belongs (see Acknowledgements). A mark from 1 to 10 , the norm in the Spanish educational system, was given for each of them.

\subsection{Data analysis: statistical methodology}

The SPSS programme, in its 21.0 version, has been used to statistically analyze the data gathered. First, through analysis of variance (ANOVA) and $t$ tests, the statistical significance of the differences between the experimental (CLIL) and control groups (mainstream EFL) were calculated so as to match participants for verbal intelligence and motivation, and thus guarantee the homogeneity and comparability of the sample.

Then, to respond to research questions (RQs) 1 through 3, ANOVA and $t$ tests have been employed again to determine the existence of statistically significant differences between groups in terms of the moderating variables considered (SES for RQs1-2, and SES, followed by verbal intelligence, motivation and extramural exposure for RQ3). Finally, in order to 
address RQ4, successive discriminant analyses have been performed to determine which variable(s) are responsible for the differences between the experimental and control groups.

\section{Results AND DisCuSSION}

\subsection{FL results according to SES}

Before looking at the specific grades, it can be detected that non-CLIL groups evince differences between the three SES levels in all the FL exams. They are statistically significant except for the speaking skill. It is interesting to highlight that a similar pattern always occurs: the higher the level, the better the marks. In contrast, the picture is not the same for CLIL streams. The aforementioned pattern does not arise now, and there are significant statistical differences only in one case, the exam block having to do with use of English (cf. Table 1).

Table 1. General FL results in terms of SES and group

\begin{tabular}{|c|c|c|c|c|c|}
\hline Group & FL skill & SES & Mean & $\begin{array}{l}\text { Standard } \\
\text { deviation }\end{array}$ & p value \\
\hline \multirow{15}{*}{ Non-CLIL } & \multirow{3}{*}{ Use of English } & Low & 13.39 & 8.79 & \multirow{3}{*}{$<0.001$} \\
\hline & & Medium & 18.49 & 10.55 & \\
\hline & & High & 23.86 & 13.18 & \\
\hline & \multirow{3}{*}{ Vocabulary } & Low & 6.63 & 3.31 & \multirow{3}{*}{$<0.001$} \\
\hline & & Medium & 7.05 & 3.36 & \\
\hline & & High & 10.00 & 3.78 & \\
\hline & \multirow{3}{*}{ Listening } & Low & 4.07 & 3.20 & \multirow{3}{*}{$<0.001$} \\
\hline & & Medium & 4.21 & 2.54 & \\
\hline & & High & 7.50 & 4.31 & \\
\hline & \multirow{3}{*}{ Reading } & Low & 1.88 & 1.76 & \multirow{3}{*}{$<0.001$} \\
\hline & & Medium & 2.36 & 2.09 & \\
\hline & & High & 4.76 & 3.42 & \\
\hline & \multirow{3}{*}{ Speaking (total) } & Low & 5.65 & 2.27 & \multirow{3}{*}{0.464} \\
\hline & & Medium & 6.27 & 2.72 & \\
\hline & & High & 6.85 & 3.12 & \\
\hline
\end{tabular}


Table 1. General FL results in terms of SES and group (Continuation)

\begin{tabular}{|c|c|c|c|c|c|}
\hline Group & FL skill & SES & Mean & $\begin{array}{l}\text { Standard } \\
\text { deviation }\end{array}$ & $p$ value \\
\hline \multirow{15}{*}{ CLIL } & \multirow{3}{*}{ Use of English } & Low & 20.04 & 10.522 & \multirow{3}{*}{0.016} \\
\hline & & Medium & 26.45 & 12.44 & \\
\hline & & High & 28.38 & 12.00 & \\
\hline & \multirow{3}{*}{ Vocabulary } & Low & 10.72 & 3.23 & \multirow{3}{*}{0.717} \\
\hline & & Medium & 10.62 & 3.35 & \\
\hline & & High & 11.16 & 3.78 & \\
\hline & \multirow{3}{*}{ Listening } & Low & 8.00 & 3.90 & \multirow{3}{*}{0.358} \\
\hline & & Medium & 7.15 & 2.37 & \\
\hline & & High & 6.96 & 3.07 & \\
\hline & \multirow{3}{*}{ Reading } & Low & 5.96 & 4.24 & \multirow{3}{*}{0.216} \\
\hline & & Medium & 4.62 & 1.90 & \\
\hline & & High & 4.93 & 3.35 & \\
\hline & \multirow{3}{*}{ Speaking (total) } & Low & 6.71 & 3.37 & \multirow{3}{*}{0.065} \\
\hline & & Medium & 8.25 & 2.55 & \\
\hline & & High & 9.41 & 0.99 & \\
\hline
\end{tabular}

Specifically concerning Primary Education, the qualification of results from mainstream EFL students in terms of this variable yields statistically significant differences for use of English, vocabulary, listening and reading (all but the speaking test). Children of parents with university studies do better in those parts of the exam than those whose parents have only completed vocational training or Baccalaureate. In turn, the latter outstrip students with parents who have studied no more than Compulsory Secondary Education. However, the picture that can be gleaned from the CLIL sample is not similar. On this occasion, the variable of SES does not yield statistically significant differences on any of the English exams. In other words, students' performance in those tests does not depend on their parents' educational level (cf. Table 2). 
Table 2. FL results of Primary Education students in terms of SES and group

\begin{tabular}{|c|c|c|c|c|c|c|}
\hline $\begin{array}{c}\text { Educational } \\
\text { level }\end{array}$ & Group & FL skill & SES & Mean & $\begin{array}{l}\text { Standard } \\
\text { deviation }\end{array}$ & p value \\
\hline \multirow{30}{*}{$\begin{array}{l}\text { Primary } \\
\text { Education }\end{array}$} & \multirow{15}{*}{ Non-CLIL } & \multirow{3}{*}{ Use of English } & Low & 7 & 5.11 & \multirow{3}{*}{0.001} \\
\hline & & & Medium & 9 & 3.60 & \\
\hline & & & High & 14.77 & 6.33 & \\
\hline & & \multirow{3}{*}{ Vocabulary } & Low & 5.46 & 3.57 & \multirow{3}{*}{0.001} \\
\hline & & & Medium & 7.33 & 2.08 & \\
\hline & & & High & 10.17 & 3.43 & \\
\hline & & \multirow{3}{*}{ Listening } & Low & 9.77 & 2.24 & \multirow{3}{*}{0.004} \\
\hline & & & Medium & 11.33 & 1.52 & \\
\hline & & & High & 12.3 & 2.13 & \\
\hline & & \multirow{3}{*}{ Reading } & Low & 1.31 & 1.93 & \multirow{3}{*}{0.001} \\
\hline & & & Medium & 5.33 & 0.57 & \\
\hline & & & High & 6.4 & 4.54 & \\
\hline & & \multirow{3}{*}{ Speaking (total) } & Low & 4 & 1.62 & \multirow{3}{*}{0.213} \\
\hline & & & Medium & 2.5 & - & \\
\hline & & & High & 6.5 & 3.21 & \\
\hline & \multirow{15}{*}{ CLIL } & \multirow{3}{*}{ Use of English } & Low & 13.23 & 7.04 & \multirow{3}{*}{0.340} \\
\hline & & & Medium & 9.83 & 6.83 & \\
\hline & & & High & 13.79 & 7.58 & \\
\hline & & \multirow{3}{*}{ Vocabulary } & Low & 10.62 & 3.82 & \multirow{3}{*}{0.433} \\
\hline & & & Medium & 8.58 & 4.10 & \\
\hline & & & High & 10.43 & 4.79 & \\
\hline & & \multirow{3}{*}{ Listening } & Low & 11.46 & 1.19 & \multirow{3}{*}{0.242} \\
\hline & & & Medium & 10.67 & 1.30 & \\
\hline & & & High & 11.50 & 1.55 & \\
\hline & & \multirow{3}{*}{ Reading } & Low & 7.54 & 5.41 & \multirow{3}{*}{0.283} \\
\hline & & & Medium & 5.00 & 2.95 & \\
\hline & & & High & 7.71 & 5.16 & \\
\hline & & \multirow{3}{*}{ Speaking (total) } & Low & 4.62 & 2.95 & \multirow{3}{*}{0.447} \\
\hline & & & Medium & 5.62 & 3.06 & \\
\hline & & & High & 8.00 & 2.12 & \\
\hline
\end{tabular}


The outcomes obtained in CSE practically concur with those of the former educational stage. SES also makes significant statistical differences emerge for non-CLIL groups in relation to use of English, vocabulary and the receptive-interpretative skills, but not oral expression. As for CLIL groups, SES again does not have an important bearing on the FL results. There are only statistically significant differences on the listening test, but -contrary to the tendency- it is not the higher rung which performs best, but the medium one (cf. Table 3).

Table 3. FL results of Compulsory Secondary Education students in terms of SES and group

\begin{tabular}{|c|c|c|c|c|c|c|}
\hline $\begin{array}{c}\text { Educational } \\
\text { level }\end{array}$ & Group & FL skill & SES & Mean & $\begin{array}{l}\text { Standard } \\
\text { deviation }\end{array}$ & p value \\
\hline \multirow{30}{*}{$\begin{array}{c}\text { Compulsory } \\
\text { Secondary } \\
\text { Education }\end{array}$} & \multirow{15}{*}{ Non-CLIL } & \multirow{3}{*}{ Use of English } & Low & 14.75 & 8.842 & \multirow{3}{*}{$<0.001$} \\
\hline & & & Medium & 19.20 & 10.579 & \\
\hline & & & High & 29.32 & 13.23 & \\
\hline & & \multirow{3}{*}{ Vocabulary } & Low & 6.88 & 3.23 & \multirow{3}{*}{$<0.001$} \\
\hline & & & Medium & 7.03 & 3.46 & \\
\hline & & & High & 9.90 & 4.01 & \\
\hline & & \multirow{3}{*}{ Listening } & Low & 2.85 & 1.72 & \multirow{3}{*}{$<0.001$} \\
\hline & & & Medium & 3.68 & 1.62 & \\
\hline & & & High & 4.62 & 2.16 & \\
\hline & & \multirow{3}{*}{ Reading } & Low & 2 & 1.71 & \multirow{3}{*}{$<0.001$} \\
\hline & & & Medium & 2.13 & 1.98 & \\
\hline & & & High & 3.78 & 2.01 & \\
\hline & & \multirow{3}{*}{ Speaking (total) } & Low & 6.40 & 2.17 & \multirow{3}{*}{0.839} \\
\hline & & & Medium & 6.75 & 2.49 & \\
\hline & & & High & 7.100 & 3.21 & \\
\hline & \multirow{15}{*}{ CLIL } & \multirow{3}{*}{ Use of English } & Low & 27.42 & 8.55 & \multirow{3}{*}{0.103} \\
\hline & & & Medium & 32.14 & 7.97 & \\
\hline & & & High & 33.37 & 8.70 & \\
\hline & & \multirow{3}{*}{ Vocabulary } & Low & 10.83 & 2.62 & \multirow{3}{*}{0.847} \\
\hline & & & Medium & 11.31 & 2.80 & \\
\hline & & & High & 11.41 & 3.40 & \\
\hline & & \multirow{3}{*}{ Listening } & Low & 4.25 & 1.48 & \multirow{3}{*}{0.002} \\
\hline & & & Medium & 5.94 & 1.11 & \\
\hline & & & High & 5.41 & 1.53 & \\
\hline & & \multirow{3}{*}{ Reading } & Low & 4.25 & 1.13 & \multirow{3}{*}{0.352} \\
\hline & & & Medium & 4.49 & 1.42 & \\
\hline & & & High & 3.98 & 1.69 & \\
\hline & & \multirow{3}{*}{ Speaking (total) } & Low & 9.50 & 0.86 & \multirow{3}{*}{0.800} \\
\hline & & & Medium & 9.56 & 0.56 & \\
\hline & & & High & 9.70 & 0.42 & \\
\hline
\end{tabular}


Thus, although some authors (Lorenzo et al., 2009; Ruiz Gómez and Nieto García, 2009; Hughes, 2010; Bruton, 2011a, 2001b, 2013) have sounded a note of caution with respect to the success of CLIL programmes being possibly attributable to the students belonging to a higher socioeconomic background, this particular analysis shows no connection between SES and FL grades in bilingual groups.

\subsection{L1 and subject content results according to SES}

A very similar pattern surfaces when L1 and subject content, the other dependent variables of this study, are considered. On the one hand, the results from both grades show that SES has a substantial effect on the EFL students' marks. On the other hand, the findings from their counterparts in dual-focused education do not yield statistically significant differences. The notion that students whose parents have a higher education levels obtain better results does not hold true in the mastery of Natural Sciences (cf. Table 4).

Table 4. General L1 and subject content in terms of SES and group

\begin{tabular}{|c|c|c|c|c|c|}
\hline Group & $\begin{array}{c}\text { Dependent } \\
\text { variables }\end{array}$ & SES & Mean & $\begin{array}{l}\text { Standard } \\
\text { deviation }\end{array}$ & $p$ value \\
\hline \multirow{6}{*}{ Non-CLIL } & \multirow{3}{*}{$\begin{array}{c}\text { Spanish } \\
\text { language }\end{array}$} & Low & 5.36 & 1.46 & \multirow{3}{*}{$<0.001$} \\
\hline & & Medium & 5.83 & 1.65 & \\
\hline & & High & 7.06 & 1.71 & \\
\hline & \multirow{3}{*}{$\begin{array}{l}\text { Subject } \\
\text { content }\end{array}$} & Low & 5.83 & 1.66 & \multirow{3}{*}{$<0.001$} \\
\hline & & Medium & 6.11 & 1.81 & \\
\hline & & High & 7.27 & 1.85 & \\
\hline \multirow{6}{*}{ CLIL } & \multirow{3}{*}{$\begin{array}{c}\text { Spanish } \\
\text { language }\end{array}$} & Low & 6.70 & 1.86 & \multirow{3}{*}{0.406} \\
\hline & & Medium & 7.10 & 1.66 & \\
\hline & & High & 7.36 & 1.82 & \\
\hline & \multirow{3}{*}{$\begin{array}{l}\text { Subject } \\
\text { content }\end{array}$} & Low & 6.75 & 1.83 & \multirow{3}{*}{0.342} \\
\hline & & Medium & 6.58 & 2.33 & \\
\hline & & High & 7.28 & 1.94 & \\
\hline
\end{tabular}

If we look at each stage, a similar picture to the one previously described transpires. At the end of Primary Education, non-CLIL learners from a higher socioeconomic status outstrip pupils from a medium one, and these -in turn- do better than children of parents with a low educational level. The varying results are significant from a statistical point of view for both the L1 and the subject content marks. Regarding CLIL branches, again, the opposite happens. The moderating variable of SES does not exert a substantial effect on the dependent variables at this stage. Surprising as it may be, low socioeconomic background learners outperform their medium level counterparts in this sense (cf. Table 5). 
Table 5. L1 and subject content results of Primary Education students in terms of SES and group

\begin{tabular}{|c|c|c|c|c|c|c|}
\hline $\begin{array}{c}\begin{array}{c}\text { Educational } \\
\text { level }\end{array} \\
\end{array}$ & Group & $\begin{array}{c}\text { Dependent } \\
\text { variables }\end{array}$ & SES & Mean & $\begin{array}{l}\text { Standard } \\
\text { deviation }\end{array}$ & p value \\
\hline \multirow{12}{*}{$\begin{array}{l}\text { Primary } \\
\text { Education }\end{array}$} & \multirow{6}{*}{ Non-CLIL } & \multirow{3}{*}{$\begin{array}{l}\text { Spanish } \\
\text { language }\end{array}$} & Low & 6.23 & 1.58 & \multirow{3}{*}{0.001} \\
\hline & & & Medium & 7.67 & 1.52 & \\
\hline & & & High & 7.96 & 1.13 & \\
\hline & & \multirow{3}{*}{$\begin{array}{l}\text { Subject } \\
\text { content }\end{array}$} & Low & 6.69 & 1.70 & \multirow{3}{*}{0.002} \\
\hline & & & Medium & 8.00 & 1.73 & \\
\hline & & & High & 8.39 & 1.13 & \\
\hline & \multirow{6}{*}{ CLIL } & \multirow{3}{*}{$\begin{array}{l}\text { Spanish } \\
\text { language }\end{array}$} & Low & 7.15 & 1.67 & \multirow{3}{*}{0.382} \\
\hline & & & Medium & 7.00 & 1.47 & \\
\hline & & & High & 7.79 & 1.42 & \\
\hline & & \multirow{3}{*}{$\begin{array}{l}\text { Subject } \\
\text { content }\end{array}$} & Low & 6.85 & 1.72 & \multirow{3}{*}{0.337} \\
\hline & & & Medium & 6.67 & 1.82 & \\
\hline & & & High & 7.64 & 1.82 & \\
\hline
\end{tabular}

The previous patterns are maintained among students finishing CSE. The means of mainstream groups differ depending on socioeconomic level, to the extent of being statistically significant. Nevertheless, the outcomes of their bilingual peers are not affected by SES, either for L1 or for subject content, as can be derived from ANOVA and $t$ tests (cf. Table 6).

Table 6. L1 and subject content results of Compulsory Secondary Education students in terms of SES and group

\begin{tabular}{|c|c|c|c|c|c|c|}
\hline $\begin{array}{c}\text { Educational } \\
\text { level }\end{array}$ & Group & $\begin{array}{c}\text { Dependent } \\
\text { variables }\end{array}$ & SES & Mean & $\begin{array}{l}\text { Standard } \\
\text { deviation }\end{array}$ & $p$ value \\
\hline \multirow{12}{*}{$\begin{array}{c}\text { Compulsory } \\
\text { Secondary } \\
\text { Education }\end{array}$} & \multirow{6}{*}{ Non-CLIL } & \multirow{3}{*}{$\begin{array}{l}\text { Spanish } \\
\text { language }\end{array}$} & Low & 4.97 & 1.23 & \multirow{3}{*}{0.001} \\
\hline & & & Medium & 5.47 & 1.45 & \\
\hline & & & High & 6.41 & 1.77 & \\
\hline & & \multirow{3}{*}{$\begin{array}{l}\text { Subject } \\
\text { content }\end{array}$} & Low & 5.45 & 1.52 & \multirow{3}{*}{0.050} \\
\hline & & & Medium & 5.73 & 1.62 & \\
\hline & & & High & 6.46 & 1.86 & \\
\hline & \multirow{6}{*}{ CLIL } & \multirow{3}{*}{$\begin{array}{l}\text { Spanish } \\
\text { language }\end{array}$} & Low & 5.86 & 2.03 & \multirow{3}{*}{0.277} \\
\hline & & & Medium & 7.16 & 1.80 & \\
\hline & & & High & 7.12 & 2.00 & \\
\hline & & \multirow{3}{*}{$\begin{array}{l}\text { Subject } \\
\text { content }\end{array}$} & Low & 6.57 & 2.14 & \multirow{3}{*}{0.702} \\
\hline & & & Medium & 6.53 & 2.65 & \\
\hline & & & High & 7.08 & 2.01 & \\
\hline
\end{tabular}


Again, these findings provide evidence that a correlation can be established between the main intervening variable under scrutiny here and L1 and subject content learning for non-CLIL groups only. In CLIL streams, SES does not have an important bearing on the results, as was the case with the FL, although it should be added that high SES students never perform the worst. This is applicable both for Primary and Secondary Education. Thus, our study does not concur with Anghel et al.'s (2016) and Fernández-Sanjurjo et al.'s (2017), who did find a connection between SES and Natural Science knowledge for bilingual strands in Primary Education (see section 2).

\subsection{The relationship between SES and the cohorts' verbal intelligence, motivation and extramural exposure}

It is also interesting to determine whether there is a relationship between SES and other moderating variables such as verbal intelligence, motivation and extramural exposure. The comparison of the general data yields some statistically significant differences among the nonCLIL groups. According to the instrument based on Santamaría et al. (2016), learners from a high socioeconomic background have a greater verbal intelligence than those from a medium one, and these in turn are more verbally intelligent than their low SES counterparts in traditional streams (whose results also evince the smallest standard deviation). The other important differences occur for two of the four factors measured by Pelechano's (1994) MA test: lack of interest in studying and realistic personal self-demand. However, regarding the general analysis of the CLIL groups' outcomes, no association can be made between these variables (cf. Table 7).

Table 7. General verbal intelligence, motivation and verbal exposure in terms of SES and group

\begin{tabular}{|c|c|c|c|c|c|}
\hline Group & $\begin{array}{c}\text { Moderating } \\
\text { variables }\end{array}$ & SES & Mean & $\begin{array}{l}\text { Standard } \\
\text { deviation }\end{array}$ & p value \\
\hline \multirow{18}{*}{ Non-CLIL } & \multirow{3}{*}{ Verbal intelligence } & Low & 9.26 & 2.77 & \multirow{3}{*}{$<0.001$} \\
\hline & & Medium & 10.63 & 3.82 & \\
\hline & & High & 12.70 & 3.83 & \\
\hline & \multirow{3}{*}{ Desire to work } & Low & 4.15 & 1.72 & \multirow{3}{*}{0.858} \\
\hline & & Medium & 4.28 & 1.63 & \\
\hline & & High & 4.30 & 1.96 & \\
\hline & \multirow{3}{*}{ Anxiety } & Low & 5.96 & 2.50 & \multirow{3}{*}{0.461} \\
\hline & & Medium & 5.53 & 2.27 & \\
\hline & & High & 6.08 & 2.17 & \\
\hline & \multirow{3}{*}{ Lack of interest } & Low & 4.96 & 2.14 & \multirow{3}{*}{0.005} \\
\hline & & Medium & 4.95 & 2.12 & \\
\hline & & High & 3.90 & 2.34 & \\
\hline & \multirow{3}{*}{ Self-demand } & Low & 1.39 & 1.31 & \multirow{3}{*}{0.020} \\
\hline & & Medium & 1.56 & 1.27 & \\
\hline & & High & 1.99 & 1.34 & \\
\hline & \multirow{3}{*}{ Extramural exposure } & Low & 13.37 & 25.37 & \multirow{3}{*}{0.240} \\
\hline & & Medium & 19.73 & 26.73 & \\
\hline & & High & 13.67 & 11.63 & \\
\hline
\end{tabular}


Table 7. General verbal intelligence, motivation and verbal exposure in terms of SES and group (Continuation)

\begin{tabular}{|c|c|c|c|c|c|}
\hline Group & $\begin{array}{c}\text { Moderating } \\
\text { variables }\end{array}$ & SES & Mean & $\begin{array}{l}\text { Standard } \\
\text { deviation }\end{array}$ & p value \\
\hline \multirow{18}{*}{ CLIL } & \multirow{3}{*}{ Verbal intelligence } & Low & 10.56 & 3.08 & \multirow{3}{*}{0.377} \\
\hline & & Medium & 10.47 & 2.69 & \\
\hline & & High & 11.27 & 3.39 & \\
\hline & \multirow{3}{*}{ Desire to work } & Low & 4.76 & 1.89 & \multirow{3}{*}{0.899} \\
\hline & & Medium & 4.60 & 2.02 & \\
\hline & & High & 4.55 & 1.87 & \\
\hline & \multirow{3}{*}{ Anxiety } & Low & 6.76 & 1.56 & \multirow{3}{*}{0.083} \\
\hline & & Medium & 6.30 & 2.06 & \\
\hline & & High & 5.75 & 2.01 & \\
\hline & \multirow{3}{*}{ Lack of interest } & Low & 4.12 & 2.12 & \multirow{3}{*}{0.824} \\
\hline & & Medium & 4.38 & 1.99 & \\
\hline & & High & 4.18 & 1.86 & \\
\hline & \multirow{3}{*}{ Self-demand } & Low & 1.72 & 1.40 & \multirow{3}{*}{0.413} \\
\hline & & Medium & 1.40 & 1.36 & \\
\hline & & High & 1.78 & 1.53 & \\
\hline & \multirow{3}{*}{$\begin{array}{c}\text { Extramural } \\
\text { exposure }\end{array}$} & Low & 21.14 & 29.58 & \multirow{3}{*}{0.998} \\
\hline & & Medium & 21.26 & 29.86 & \\
\hline & & High & 20.91 & 16.85 & \\
\hline
\end{tabular}

Once the data is qualified in terms of grade, the situation does not coincide with the one presented above. Vis-à-vis Primary Education, our search for connections between SES and the other three moderating variables enables the possibility of establishing only a clear one for the traditional EFL branches and none for the bilingual ones. Analyzing the relationship between socioeconomic background and verbal intelligence produces statistically significant differences, but not in the way many would have predicted. The non-CLIL children with more verbal intelligence are those whose parents have a medium level of educational attainment (cf. Table 8).

There are other findings obtained here that, in our view, are quite interesting and worth highlighting despite not being important, statistically speaking, and involving the joint examination of several variables. First, the match between SES and verbal intelligence is quite similar to the correspondence between SES and extramural exposure to English -both for the control and the experimental groups, but especially for the former. This provides an opportunity to explore the possible relationship between verbal intelligence and exposure to the FL outside the classroom. Second, in CLIL streams, low SES pupils have more anxiety and interest than the rest, and more desire to work than their high SES peers. This is tremendously positive if it is interpreted that these students are very committed to their (bilingual) learning despite coming from a background which could pose more difficulties in that respect (this would explain their high anxiety levels as well) (cf. Table 8). 
Table 8. Motivation, verbal intelligence and extramural exposure of Primary Education students in terms of SES and group

\begin{tabular}{|c|c|c|c|c|c|c|}
\hline $\begin{array}{c}\begin{array}{c}\text { Educational } \\
\text { level }\end{array} \\
\end{array}$ & Group & $\begin{array}{c}\text { Moderating } \\
\text { Variables } \\
\end{array}$ & SES & Mean & $\begin{array}{l}\text { Standard } \\
\text { deviation }\end{array}$ & $p$ value \\
\hline \multirow{36}{*}{$\begin{array}{l}\text { Primary } \\
\text { Education }\end{array}$} & \multirow{18}{*}{ Non-CLIL } & \multirow{3}{*}{$\begin{array}{c}\text { Verbal } \\
\text { intelligence }\end{array}$} & Low & 10.23 & 2.16 & \multirow{3}{*}{0.014} \\
\hline & & & Medium & 16.67 & 8.50 & \\
\hline & & & High & 13.37 & 3.87 & \\
\hline & & \multirow{3}{*}{$\begin{array}{c}\text { Desire to } \\
\text { work }\end{array}$} & Low & 5.62 & 1.98 & \multirow{3}{*}{0.150} \\
\hline & & & Medium & 4.33 & 1.52 & \\
\hline & & & High & 4.31 & 2.02 & \\
\hline & & \multirow{3}{*}{ Anxiety } & Low & 6.67 & 1.72 & \multirow{3}{*}{0.934} \\
\hline & & & Medium & 6.67 & 0.57 & \\
\hline & & & High & 6.47 & 1.75 & \\
\hline & & \multirow{3}{*}{$\begin{array}{l}\text { Lack of } \\
\text { interest }\end{array}$} & Low & 3.54 & 2.10 & \multirow{3}{*}{0.238} \\
\hline & & & Medium & 1.67 & 0.57 & \\
\hline & & & High & 2.67 & 1.95 & \\
\hline & & \multirow{3}{*}{ Self-demand } & Low & 1.92 & 1.73 & \multirow{3}{*}{0.765} \\
\hline & & & Medium & 1.67 & 2.08 & \\
\hline & & & High & 2.17 & 1.17 & \\
\hline & & \multirow{3}{*}{$\begin{array}{l}\text { Extramural } \\
\text { exposure }\end{array}$} & Low & 6.57 & 4.67 & \multirow{3}{*}{0.095} \\
\hline & & & Medium & 19.16 & 23.85 & \\
\hline & & & High & 10.77 & 8.78 & \\
\hline & \multirow{18}{*}{ CLIL } & \multirow{3}{*}{$\begin{array}{c}\text { Verbal } \\
\text { intelligence }\end{array}$} & Low & 11.54 & 3.35 & \multirow{3}{*}{0.369} \\
\hline & & & Medium & 10.83 & 3.29 & \\
\hline & & & High & 12.86 & 4.22 & \\
\hline & & \multirow{3}{*}{$\begin{array}{l}\text { Desire to } \\
\text { work }\end{array}$} & Low & 5.38 & 1.85 & \multirow{3}{*}{0.925} \\
\hline & & & Medium & 5.50 & 1.83 & \\
\hline & & & High & 5.21 & 1.88 & \\
\hline & & \multirow{3}{*}{ Anxiety } & Low & 6.85 & 1.62 & \multirow{3}{*}{0.369} \\
\hline & & & Medium & 6.42 & 2.19 & \\
\hline & & & High & 5.71 & 2.33 & \\
\hline & & \multirow{3}{*}{$\begin{array}{l}\text { Lack of } \\
\text { interest }\end{array}$} & Low & 3.00 & 1.87 & \multirow{3}{*}{0.808} \\
\hline & & & Medium & 3.42 & 2.15 & \\
\hline & & & High & 3.50 & 2.24 & \\
\hline & & \multirow{3}{*}{ Self-demand } & Low & 1.92 & 1.32 & \multirow{3}{*}{0.274} \\
\hline & & & Medium & 1.40 & 1.43 & \\
\hline & & & High & 2.46 & 1.80 & \\
\hline & & \multirow{3}{*}{$\begin{array}{l}\text { Extramural } \\
\text { exposure }\end{array}$} & Low & 16.57 & 32.40 & \multirow{3}{*}{0.450} \\
\hline & & & Medium & 6.43 & 6.22 & \\
\hline & & & High & 16.21 & 19.87 & \\
\hline
\end{tabular}


At the end of Compulsory Secondary Education, the previous trend is reinforced. This co-variate analysis only evinces statistically significant differences between SES and verbal intelligence of non-CLIL students. Nonetheless, on this occasion, unlike the former educational stage, high SES learners are those who are more verbally intelligent. Further interesting results which should be remarked are the following: extramural exposure to the FL is greater than in Primary Education, especially among CLIL students (standard deviations are always high regardless of SES), and -on the negative side- CLIL learners of low SES reportedly have less desire to work, less interest in learning and more anxiety in the face of exams than their counterparts. Therefore, special attention will have to be paid to this particular group so that it does not lose its motivation towards (bilingual) learning throughout CSE (cf. Table 9).

Table 9. Motivation, verbal intelligence and extramural exposure of Compulsory Secondary Education students in terms of SES and group

\begin{tabular}{|c|c|c|c|c|c|c|}
\hline $\begin{array}{c}\text { Educational } \\
\text { level }\end{array}$ & Group & $\begin{array}{c}\text { Moderating } \\
\text { variables }\end{array}$ & SES & Mean & $\begin{array}{l}\text { Standard } \\
\text { deviation }\end{array}$ & $p$ value \\
\hline \multirow{18}{*}{$\begin{array}{c}\text { Compulsory } \\
\text { Secondary } \\
\text { Education }\end{array}$} & \multirow{18}{*}{ Non-CLIL } & \multirow{3}{*}{$\begin{array}{c}\text { Verbal } \\
\text { intelligence }\end{array}$} & Low & 9.05 & 2.85 & \multirow{3}{*}{$<0.001$} \\
\hline & & & Medium & 10.18 & 3.00 & \\
\hline & & & High & 12.30 & 3.78 & \\
\hline & & \multirow{3}{*}{ Desire to work } & Low & 3.84 & 1.50 & \multirow{3}{*}{0.280} \\
\hline & & & Medium & 4.28 & 1.66 & \\
\hline & & & High & 4.30 & 1.95 & \\
\hline & & \multirow{3}{*}{ Anxiety } & Low & 5.82 & 2.62 & \multirow{3}{*}{0.710} \\
\hline & & & Medium & 5.45 & 2.33 & \\
\hline & & & High & 5.84 & 2.37 & \\
\hline & & \multirow{3}{*}{ Lack of interest } & Low & 5.26 & 2.04 & \multirow{3}{*}{0.260} \\
\hline & & & Medium & 5.20 & 1.99 & \\
\hline & & & High & 4.64 & 2.26 & \\
\hline & & \multirow{3}{*}{ Self-demand } & Low & 1.29 & 1.20 & \multirow{3}{*}{0.066} \\
\hline & & & Medium & 1.55 & 1.23 & \\
\hline & & & High & 1.88 & 1.43 & \\
\hline & & \multirow{3}{*}{$\begin{array}{l}\text { Extramural } \\
\text { exposure }\end{array}$} & Low & 14.82 & 27.69 & \multirow{3}{*}{0.558} \\
\hline & & & Medium & 19.77 & 27.20 & \\
\hline & & & High & 15,41 & 12,82 & \\
\hline
\end{tabular}


Table 9. Motivation, verbal intelligence and extramural exposure of Compulsory Secondary education students in terms of SES and group (Continuation)

\begin{tabular}{|c|c|c|c|c|c|c|}
\hline $\begin{array}{c}\text { Educational } \\
\text { level }\end{array}$ & Group & $\begin{array}{l}\text { Moderating } \\
\text { variables }\end{array}$ & SES & Mean & $\begin{array}{l}\text { Standard } \\
\text { deviation }\end{array}$ & P value \\
\hline \multirow{18}{*}{$\begin{array}{c}\text { Compulsory } \\
\text { Secondary } \\
\text { Education }\end{array}$} & \multirow{18}{*}{ CLIL } & \multirow{3}{*}{$\begin{array}{c}\text { Verbal } \\
\text { intelligence }\end{array}$} & Low & 9.50 & 2.46 & \multirow{3}{*}{0.379} \\
\hline & & & Medium & 10.34 & 2.49 & \\
\hline & & & High & 10.73 & 2.92 & \\
\hline & & \multirow{3}{*}{ Desire to work } & Low & 4.08 & 1.78 & \multirow{3}{*}{0.931} \\
\hline & & & Medium & 4.29 & 2.02 & \\
\hline & & & High & 4.32 & 1.83 & \\
\hline & & \multirow{3}{*}{ Anxiety } & Low & 6.67 & 1.55 & \multirow{3}{*}{0.284} \\
\hline & & & Medium & 6.26 & 2.04 & \\
\hline & & & High & 5.76 & 1.92 & \\
\hline & & \multirow{3}{*}{$\begin{array}{l}\text { Lack of } \\
\text { interest }\end{array}$} & Low & 5.33 & 1.72 & \multirow{3}{*}{0.280} \\
\hline & & & Medium & 4.71 & 1.85 & \\
\hline & & & High & 4.41 & 1.68 & \\
\hline & & \multirow{3}{*}{ Self-demand } & Low & 1.50 & 1.50 & \multirow{3}{*}{0.878} \\
\hline & & & Medium & 1.39 & 1.36 & \\
\hline & & & High & 1.56 & 1.39 & \\
\hline & & \multirow{3}{*}{$\begin{array}{l}\text { Extramural } \\
\text { exposure }\end{array}$} & Low & 26.08 & 26.69 & \multirow{3}{*}{0.787} \\
\hline & & & Medium & 26.34 & 33.01 & \\
\hline & & & High & 22.52 & 15.64 & \\
\hline
\end{tabular}

\subsection{Explaining the competence differential in FL, $L 1$ and subject matter learning}

Finally, all these variables have been subjected to discriminant analyses in order to determine which of them explains the greatest variance in language attainment and content achievement results. With this statistical technique, we have strived to assess the discriminating potential of the different independent and moderating variables with which we have undertaken this research in the CLIL and non-CLIL groups. As the aim is to isolate the variables which best explain the statistically significant differences ascertained between the groups, successive discriminant analyses have been performed to select those which display the greatest significance in the tests of equality of group means.

The analyses reveal that there are no differences between the bilingual and non-bilingual groups in Primary Education that are ascribable to any of the variables. On the contrary, in Secondary Education the variance in language attainment and content achievement results is attributable to the independent variable (the CLIL programme). Moreover, results show that extramural exposure to English also carries a significant weight in explaining the dissimilarities between the groups at this stage, as ascertained by Sylvén and Sundqvist (2015: 59) in their research (cf. Tables 10 and 11). 
Table 10. Test of equality of group means

\begin{tabular}{|c|c|c|c|c|c|}
\hline Primary Education & $\begin{array}{c}\text { Wilks' } \\
\text { Lambda }\end{array}$ & $\mathbf{F}$ & gl1 & gl2 & Sig. \\
\hline Secondary Education & $\begin{array}{c}\text { Wilks' } \\
\text { Lambda }\end{array}$ & $\mathbf{F}$ & gl1 & gl2 & Sig. \\
\hline L1 grades & 0.910 & 13.026 & 1 & 131 & 0.000 \\
\hline Natural Science grades & 0.965 & 4.702 & 1 & 131 & 0.032 \\
\hline Extramural exposure & 0.916 & 11.947 & 1 & 131 & 0.001 \\
\hline Use of English & 0.935 & 9.053 & 1 & 131 & 0.003 \\
\hline Vocabulary & 0.917 & 11.915 & 1 & 131 & 0.001 \\
\hline Listening & 0.884 & 17.257 & 1 & 131 & 0.000 \\
\hline Reading & 0.969 & 4.188 & 1 & 131 & 0.043 \\
\hline
\end{tabular}

Table 11. Summary of canonical discriminant functions

\begin{tabular}{|c|c|c|c|c|c|c|}
\hline \multicolumn{7}{|c|}{ Primary Education } \\
\hline Function & \multicolumn{2}{|c|}{ Eigenvalue } & \multicolumn{2}{|c|}{$\%$ of variance } & Cumulative \% & Canonical correlation \\
\hline 1 & \multicolumn{2}{|c|}{0.451} & \multicolumn{2}{|c|}{100.0} & 100.0 & 0.557 \\
\hline \multicolumn{2}{|c|}{ Test of functions } & \multicolumn{2}{|c|}{ Wilks' Lambda } & \multicolumn{2}{|c|}{ Chi-square } & Sig. \\
\hline \multicolumn{2}{|c|}{1} & \multicolumn{2}{|c|}{0.689} & \multicolumn{2}{|c|}{25.481} & 13 \\
\hline \multicolumn{7}{|c|}{ Secondary Education } \\
\hline Function & \multicolumn{2}{|c|}{ Eigenvalue } & \multicolumn{2}{|c|}{$\%$ of variance } & Cumulative \% & Canonoical correlation \\
\hline 1 & \multicolumn{2}{|c|}{0.294} & \multicolumn{2}{|c|}{100.0} & 100.0 & 0.477 \\
\hline \multicolumn{2}{|c|}{ Test of functions } & \multicolumn{2}{|c|}{ Wilks' Lambda } & \multicolumn{2}{|c|}{ Chi-square } & Sig. \\
\hline \multicolumn{2}{|c|}{1} & \multicolumn{2}{|c|}{0.773} & \multicolumn{2}{|c|}{32.868} & 0.000 \\
\hline
\end{tabular}

\section{Conclusion}

The present investigation sheds light on the impact of the socioeconomic variable on language and content attainment in CLIL contexts. Non-CLIL groups were also sampled, and the study was conducted with students enrolled at the end of Primary and Compulsory Secondary Education. 
In response to the first RQ, it can be argued that the performance of bilingual students in the FL does not vary depending on their parents' educational level. This is not the case in non-CLIL contexts, where there are important differences between high, medium and low SES learners in their foreign language attainment. This is noticeable both in Primary Education and in CSE.

Vis-á-vis the second RQ, the moderating variable of SES does not exert any substantial effect on the other two dependent variables of the study in CLIL streams. Outcomes again coincide no matter what the level is. The data presented here shows that better language and content attainment of bilingual students is not clearly attributable to the socioeconomic background to which they belong. On the contrary, SES does have an important effect on L1 and content knowledge in traditional EFL groups, not only at the end of Primary Education but also of CSE.

Interestingly, these results do not concur with those yielded by previously conducted investigations in Primary Education about the effects of SES on the subject content learning of bilingual groups (cf. Anghel et al., 2016, and Fernández-Sanjurjo et al., 2017), so we encourage further empirical evidence, with even a larger and more varied sample and in other settings. Undoubtedly, exploring the impact of this factor on the FL and L1 of CLIL students would also be very welcome.

As far as the third RQ is concerned, the co-variate analysis evinces no statistically significant differences. Interestingly, there are some dissimilarities between the socioeconomic categories of these groups having to do with low SES pupils outperforming all of their high SES peers in Primary Education in terms of anxiety, interest in learning and desire to work, but underperforming them at the end of CSE, which means that the picture is flipped. A positive note is that extramural exposure increases from one grade to another regardless of the parental level of studies.

Turning to the fourth and final RQ, subjecting all the variables to discriminant analyses allows us to ascertain that none of them explains the variance in language attainment and content achievement results obtained in Primary Education. On the contrary, academic factors such as performance in the L1, FL and content exams account for the greatest amount of variance in Secondary Education, in addition to exposure to the English language outside the classroom.

Finally, some pedagogical implications can be derived from our findings. First of all, parents of low (and medium or high, obviously) socioeconomic background should not step back in the enrollment of their children in CLIL strands, if this has been the case in some families. They can do academically as well as students in the upper rungs. Thus, it is recommended that the CLIL programme reach all cities and towns. We strongly encourage the Spanish Autonomous Community of Andalusia (and any other region/country in Spain and abroad which may be planning this) to continue with the initiative of moving from bilingual sections to bilingual schools.

Secondly, we have detected a negative evolution that must not be neglected. Primary education children of low SES report having more interest than the rest, and more desire to work than their high SES peers. They also admit to being more anxious. These results in motivation can be interpreted as positive at the first glance, on the basis of commitment to their (bilingual) learning in spite of coming from a background which in principle poses more difficulties for them. 
However, the outcomes obtained from their counterparts in the CSE bilingual branches are worrying. In this second stage, they have less desire to work, less interest in learning and are more anxious in the face of exams than their medium and high SES peers. This points to the need of maintaining interest in this particular group so that it does not lose its motivation towards (bilingual) learning throughout CSE. If motivation is at risk, academic performance will also be.

A third and last teaching idea that can be gleaned from this study has to do with the successive discriminant analyses determining the important weight of exposure to English in the L1, FL and content results. In bilingual groups, low-SES children devote more time to activities in English outside the classroom than high-SES ones, both in Primary and especially in Secondary Education. This is probably a reason why there are no significant statistical differences in CLIL groups in terms of SES as regards language and content attainment.

Those hours of exposure to English away from the school could be the key to preventing the low-SES students' decreasing motivation throughout Compulsory Secondary Education. As Sylvén and Sundqvist argue (2015: 59), extramural English is "a good complement and possibly also a motivating starting point for intramural teaching and learning". They believe that teachers must acknowledge that extramural activities are very important for language learning and that they must know them well, so as to be aware of what their pupils like to engage in. This could be a way of raising the motivation of low-SES students. Studying diversity may be the key to maintaining students' interest. This is undoubtedly an area to which the forthcoming CLIL agenda must be oriented.

\section{REFERENCES}

Alejo, R. and Piquer-Píriz, A. (2016). "Urban vs. rural CLIL: An analysis of input-related variables, motivation and language attainment", in Language, Culture and Curriculum, 29, 3: 245-262.

Alonso, E., Grisaleña, J. and Campo, A. (2008). "Plurilingual education in secondary schools: Analysis of results", in International CLIL Journal, 1, 1: 36-49.

Anghel, B., Cabrales, A. and Carro, J.M. (2016). "Evaluating a bilingual education programme in Spain: The impact beyond foreign language learning", in Economic Inquiry, 54, 2: 1202-1223.

Bruton, A. (2011a). "Are the differences between CLIL and non-CLIL groups in Andalusia due to CLIL?" A reply to Lorenzo, Casal and Moore (2010), in Applied Linguistics, 2011: 1-7.

Bruton, A. (2011b). "Is CLIL so beneficial, or just selective? Re-evaluating some of the Research", in System, 39: 523-532.

Bruton, A. (2013). "CLIL: Some of the reasons why... and why not", in System, 41: 587-597.

Fernández-Sanjurjo, J., Fernández-Costales, A. and Arias Blanco, J. M. (2017). “Analysing students' content-learning in science in CLIL vs. non-CLIL programmes: Empirical evidence from Spain", in International Journal of Bilingual Education and Bilingualism, 1-14.

Lorenzo, F., Casal, S. and Moore, P. (2011). "On complexity in bilingual research: The causes, effects, and breadth of content and language integrated learning”. A reply to Bruton (2011), in Applied Linguistics, 32, 4: 450-455.

Paran, A. (2013). "Content and language integrated learning: Panacea or policy borrowing myth?", in Applied Linguistics Review, 4, 2: 317-342. 
Pelechano, V. (1994). "Prueba MA", in Análisis y Modificación de la Conducta, 20: 71-72.

Pérez Cañado, M. L. (2012). "CLIL research in Europe: Past, present, and future", in International Journal of Bilingual Education and Bilingualism, 15, 3: 315-341.

Pérez Cañado, M. L. (2016). "Stopping the "pendulum effect" in CLIL research: Finding the balance between Pollyanna and Scrooge", in Applied Linguistics Review, DOI 10.1515/ applirev-2016-2001.

Santamaría, P. Arribas, D., Pereña, J. and Seisdedos, N. (2016). EFAI. Evaluación factorial de las aptitudes intelectuales. Madrid: TEA Ediciones.

Sundqvist, P. and Sylvén, L. K. (2014). "Language-related computer use: Focus on young L2 English learners in Sweden", in ReCALL, 26, 1: 3-20.

Sylvén, L. K. and Sundqvist, P. (2015). "Extramural English in relation to CLIL: Focus on young language learners in Sweden”, in D. Marsh, M. L. Pérez Cañado and J. Ráez Padilla (eds.), CLIL in action. Voices from the classroom. Newcastle upon Tyne: Cambridge Scholars Publishing, 47-62.

\section{ACKNOWLedgements}

This work was supported by the Spanish Ministry of Economy and Competitiveness, under Grant FFI2012-32221, and by the Junta de Andalucía, under Grant P12-HUM-23480. 